\title{
13. Can We Feminise Human Rights? ${ }^{1}$
}

\author{
Margaret Thornton
}

In view of the malaise besetting the Sex Discrimination Act 1984 (Cth) (SDA), this chapter considers whether a national charter of human rights might be able to re-energise it. With particular regard to the Brennan proposal, the chapter overviews the foundational UN conventions that underpin this initiative and similar domestic charters. The issues of universalism, equality and intersectionality are examined as possessing particular gendered significance. Attention is drawn to the suspicion and scepticism that tend to affect legally binding human rights instruments in the Australian context, which have resulted in an approach that favours rhetoric over a commitment to substantive equality. It is suggested that the immunity accorded private sector actors is a striking example of an overly cautious approach.

\section{Introduction}

Human rights have become what Costas Douzinas terms 'the lingua franca of the New Times'. ${ }^{2}$ Animated by economic globalisation and the 'War on Terror', human rights have made a dramatic return to the world stage. In this chapter, I set out to explore the significance of human rights for Australian women against the backdrop of the Sex Discrimination Act 1984 (Cth) (SDA). The exploration is somewhat tentative because the Commonwealth has neither an entrenched bill of rights nor a statutory charter, although legislation was proposed by the National Human Rights Consultation Report (Brennan Report) in 2009. ${ }^{3}$ In addition to considering this proposal, the discussion will be informed by the conjunction of discrimination and human rights statutes enacted in the Australian Capital Territory, ${ }^{4}$ Victoria ${ }^{5}$ and the United Kingdom, ${ }^{6}$ which espouse a similar dialogic model.

\footnotetext{
1 A version of this chapter was presented at the 2010 Annual Meeting of the Law and Society Association, Chicago, 27-30 May 2010. Thanks to Dr Trish Luker for research assistance.

2 Costas Douzinas, 'The End(s) of Human Rights' (2002) 26 Melbourne University Law Review $445,453$.

3 Commonwealth of Australia, National Human Rights Consultation Report, Commonwealth of Australia, Canberra, 2009 [Brennan Report].

4 Human Rights Act 2004 (ACT) (HRA [ACT]).

5 Charter of Human Rights and Responsibilities Act 2006 (Vic.) (Victorian Charter).

6 Human Rights Act 1998 (UK) (HRA [UK]).
} 
As ably demonstrated by the contributors to this collection, the $S D A$ represents a crucial step in the protracted struggle by Australian women to be accepted as full citizens but it falls well short of securing substantive equality. Most notably, discrimination is proscribed only in certain areas of public life, which means that the private sphere - the source of many gender inequities - remains largely immunised against challenge despite the fact that the Convention on the Elimination of All Forms of Discrimination Against Women (CEDAW) is not so constrained. Even within the public sphere, the $S D A$ has been unable to address adequately the intransigent discriminatory structures that lie deep within the social psyche, such as the discomfiting relationship between the feminine and authority. An individualised and ad-hoc, complaint-based anti-discrimination system simply cannot disinter and confront systemic discrimination that is imbricated with power.

Despite the fact that identity is constituted in complex ways in terms of sex, race, sexuality, religion and a range of other characteristics, the approach of the SDA and similar Australian anti-discrimination legislation tends to be onedimensional and essentialist. That is, a complainant is expected to focus on sex or race or sexuality, or other identifiable characteristics rather than sex plus race, or sex plus sexuality, or some other combination of grounds. ${ }^{7}$ Intersectionality is implicitly discouraged at the federal level because of the separate Acts. ${ }^{8}$ Hence, an Indigenous woman who lodges a complaint under the $S D A$ is expected to slough off the elements of race that go to shape her identity, regardless of the extent to which it contributed to the harm she endured. Similarly, if she lodges her complaint under the Racial Discrimination Act 1975 (Cth) (RDA), she is expected to present herself as sex-less. A similarly vexed choice besets all complaints arising from multiple grounds. ${ }^{9} \mathrm{I}$ interpolate here that class is completely invisible in anti-discrimination legislation, even though economic status and education are key determinants of autonomy and freedom in our society. The class element in sex plus class or sex plus race plus class is always sloughed off so that it is worth considering whether a national charter of rights might be able to step into the breach.

\footnotetext{
7 'Sex plus' has been recognised in the US jurisprudence of the Civil Rights Act for many years, although it is by no means unproblematic. See, for example: Susan J. Best, 'Sexual Favoritism: A Cause of Action Under a "Sex-Plus" Theory' (2009) 30 Northern Illinois University Law Review 211; Enrique Schaere, 'Intragroup Discrimination in the Workplace: The Case for "Race Plus"' (2010) 45 Harvard Civil Rights-Civil Liberties Law Review 57.

8 Racial Discrimination Act 1975; Sex Discrimination Act 1984; Disability Discrimination Act 1992; Age Discrimination Act 2004. The streamlining of these Acts into a single Act has been announced. See AttorneyGeneral Hon. Robert McClelland MP and Minister for Finance and Deregulation Hon. Lindsay Tanner MP, Reform of Anti-discrimination Legislation, Media release, 21 April 2010, Parliament House, Canberra. This will not, however, automatically overcome the uni-dimensionality problem, which is thoroughly entrenched in the discrimination jurisprudence of omnibus State and Territory Acts.

9 Australian Law Reform Commission, Equality Before the Law: Justice for Women, Report No. 69, Australian Law Reform Commission, Sydney, 1994, Part I, pp. 63-9.
} 
There is also the $S D A^{\prime}$ 's lack of flexibility in being able to respond to changed economic and socio-political circumstances-most notably the passionate embrace of the free market, which has impacted significantly on working women even though female workforce participation has increased. ${ }^{10}$ At the turn of the millennium, job tenure became parlous and contingent work expanded, with stable, full-time work becoming a relic of the past for many. ${ }^{11}$ Consequently, the movement towards gender equality at work was stymied as women were deployed to legitimise the expansion of global capital. ${ }^{12}$ Perversely, the neoliberal swing and the market embrace caused inequality rather than equality to become the dominant social norm. ${ }^{13}$ Neo-liberalism also went hand in glove with moral conservatism, which saw women's human rights interests disappear from political and policy agendas in favour of 'gender mainstreaming' ${ }^{14}$ In evidence presented at a recent review of the $S D A$, it is noteworthy that even the federal Sex Discrimination Commissioner, Elizabeth Broderick, considered the progress of the SDA to have stalled. ${ }^{15}$

Feminist legal scholarship has devoted surprisingly little attention to the fate of domestic human rights in the face of globalisation, although an astonishing proliferation of literature on gender and international human rights began to emerge in the $1980 \mathrm{~s}^{16}$ - at the same time as the genesis of the SDA. Legal feminism has undoubtedly been captivated by the 'endearingly grand' themes of peace and equality in an international frame. ${ }^{17}$ Why is this so? According to Thérèse Murphy, more optimism is associated with international law. ${ }^{18}$ It could also be that the Australian legal academy has been seduced by 'northern hemispherism', as well as the need to demonstrate the international relevance of its scholarship. ${ }^{19}$

\footnotetext{
10 In 2008, the labour force participation of women was 58 per cent (<http://www.dfat.gov.au/facts/women. html $>$ ).

11 For example: Judy Fudge and Rosemary Owens (eds), Precarious Work, Women and the New Economy: The Challenge to Legal Norms, Hart Publishing, Oxford, 2006; A. B. Sukert, 'Marionettes of Globalization: A Comparative Analysis of Legal Protections for Contingent Workers in the International Community' (2000) 27 Syracuse Journal of International Law \& Commerce 431.

12 Hester Eisenstein, ‘A Dangerous Liaison? Feminism and Corporate Globalization' (2005) 69 Science \& Society 487.

13 Margaret Thornton, 'Free Trade and Justice: A Discomfiting Liaison' in Kevin Walton, Helen Irving and Jacqui Mowbray (eds), Julius Stone: A Study of Influence, Federation Press, Sydney, 2010.

14 Marian Sawer, 'Disappearing Tricks' (2008) 27(3) Dialogue: Academy of the Social Sciences in Australia 4.

15 Evidence presented to Senate Standing Committee on Legal Constitutional Affairs (Report on the Effectiveness of the Commonwealth Sex Discrimination Act 1984 in Eliminating Discrimination and Promoting Gender Equality, Commonwealth of Australia, Canberra, 2008, p. 47).

16 Karen Engle, 'International Human Rights and Feminisms: When Discourses Keep Meeting' in Doris Buss and Ambreena Manji (eds), International Law: Feminist Approaches, Hart, Oxford, 2005, p. 47.

17 Thérèse Murphy, 'Feminism Here and Feminism There: Law, Theory and Choice' in Doris Buss and Ambreena Manji (eds), International Law: Modern Feminist Approaches, Hart, Oxford, 2005, p. 77.

18 Ibid.

19 The Excellence in Research for Australia (ERA) emphasises metrics that include international standing and journal rankings (<http://www.arc.gov.au/era/era_2010.htm $>$ ).
} 
In light of the contemporary malaise at the domestic level, it is worth considering whether a charter might be able to re-energise the $S D A$ or provide an alternative course of action. ${ }^{20}$ As human rights instruments have emerged from a neo-liberal climate where the market is the measure of all things, one cannot help but feel just a tad sceptical at the outset. The political backdrop to introducing a domestic charter is also one of suspicion and scepticism.

In weighing up the pros and cons, I review the concept of human rights, a claimed universal but with a masculinist bias, which has had currency in an international rather than a domestic context as far as Australia is concerned; I consider the UN conventions that underpin domestic charters, drawing attention to the preference for form over substance, showing how these values are mirrored in the Brennan proposal; I then consider the pre-eminent values of liberalism - freedom and equality - which are privileged in human rights charters but are in perpetual tension with one another; finally, I look at intersectional discrimination claims as an exemplary site where a charter might be invoked to ameliorate a fundamental weakness of the SDA and other antidiscrimination legislation.

\section{Human Rights and the Challenge of Universalism}

The universalism of human rights carries a certain appeal as it means that rights apply to everyone regardless of sex or other characteristic of identity. When we look below the surface, however, a paradox quickly manifests itself: 'Human rights must be universal if they are to apply to all people and in all places... And yet, being universal, they must be expressed so as to have a strong resonance for all people, regardless of race, religion, sex or culture. ${ }^{21}$

We all believe that we have some idea of what it is to be human, but, as soon as we move beyond the material needs of food, water and shelter ${ }^{22}$ to rights in the abstract, disagreement surfaces, and cultural and contextual factors insistently disrupt the universal claim.

\footnotetext{
20 The Fair Work Act 2009 (Cth) (s. 342) provides another option that could prove to be more effective than anti-discrimination law in employment complaints. See: Carol Andrades, Intersections Between 'General Protections' under the Fair Work Act 2009 (Cth) and Anti-Discrimination Law: Questions, Quirks and Quandaries, Working Paper No. 47, Centre for Employment and Labour Relations Law, University of Melbourne, Vic., 2009.

21 Peter Bailey, The Human Rights Enterprise in Australia and Internationally, LexisNexis Butterworths, Chatswood, NSW, 2009, p. 4.

22 Any concept of a 'minimum core' is itself indeterminate, as argued by Katharine G. Young, 'The Minimum Core of Economic and Social Rights: A Concept in Search of Content' (2008) 33 Yale Journal of International Law 113.
} 
A definition of rights must also include an agonistic element. To this end, Sjoberg et al. define human rights as 'social claims made by individuals (or groups) upon organized power arrangements for the purpose of enhancing human dignity' ${ }^{23}$ Without avenues for redress, the exploitative and oppressive acts of the powerful remain hidden, and human rights are consigned to a merely rhetorical plane, although the morality of what is right and what is wrong engenders endless contestation. An element of presbyopia, for example, underpins the Eurocentricism of human rights discourse. Indeed, it was long averred that human rights were unproblematic or irrelevant in the Australian domestic context because violations occurred mainly in illiberal regimes, such as South American dictatorships or developing states. This international/domestic dichotomy is also a subtext of women's human rights.

The insistence that women's rights are human rights has become a rallying cry of the international feminist movement, ${ }^{24}$ but one that is echoed only faintly at the domestic level where sex discrimination discourse operates in a different register. The idea that there might be a constellation of human rights specific to women was long viewed with incomprehension by the mainstream, ${ }^{25}$ and it was suggested that the masculine domination of the United Nations and its agencies contributed to the construction of 'human rights as men's rights' ${ }^{26}$ Such a construction, however, draws on 2000 years of the Western intellectual tradition, during which time 'the human' acquired a totalising meaning, equating it with the masculine and relegating the feminine to the Other. ${ }^{27}$ This gendered dualism, which has shaped the entire panoply of liberal rights discourse, has presumed the rights holder to be 'an ontologically autonomous, self-sufficient, unencumbered subject ${ }^{28}$ that has historically excluded women.

Only in recent years have international human rights bodies begun to acknowledge the more extreme violations of women's human rights, such as torture, trafficking, slavery and violence. ${ }^{29}$ Metonymically, these embodied acts of violence, often associated with international armed conflict, have come to be

23 Gideon Sjoberg, Elizabeth A. Gill and Norma Williams, 'A Sociology of Human Rights' (2001) 48 Social Problems 11, 42.

24 Siobhán Mullally, Gender, Culture and Human Rights: Reclaiming universalism, Hart, Oxford and Portland, Ore., 2006, p. ix.

25 Charlotte Bunch, 'Transforming Human Rights from a Feminist Perspective' in Julie Peters and Andrea Wolper (eds), Women's Rights, Human Rights, Routledge, New York, 1995, p. 12.

26 Hilary Charlesworth, 'Human Rights as Men's Rights' in Julie Peters and Andrea Wolper (eds), Women's Rights, Human Rights, Routledge, New York, 1995. Cf. Rebecca Cook, 'Women's International Human Rights Law: The Way Forward' in Rebecca Cook (ed.), Human Rights of Women: National and International Perspectives, University of Pennsylvania Press, Philadelphia, 1994, p. 3.

27 The most detailed exposition of this proposition remains that of Simone de Beauvoir (The Second Sex, Translated and edited by H. M. Parshley, Four Square, London, 1966).

28 Wendy Brown, 'Suffering Rights as Paradoxes' (2000) 7 Constellations 230, 239.

29 Elissavet Stamatopoulon, 'Women's Rights and the United Nations' in Julie Peters and Andrea Wolper (eds), Women's Rights, Human Rights, Routledge, New York, 1995, pp. 38-9. 
equated with the sum total of women's human rights. The result is that there is a reluctance to view other manifestations of discrimination, such as those that detrimentally affect women economically and socially, as conduct that violates their human rights. ${ }^{30}$ As Rachael Johnstone points out, gender discrimination is tolerated in ways that would be viewed as totally unacceptable in the case of race. ${ }^{31}$ The individualisation of sex discrimination complaints also serves to construct acts of discrimination as aberrant and ad hoc-in contrast with the supposedly universal or class-wide character of human rights. This is despite years of endeavour by feminist scholars to emphasise the systemic character of sex discrimination. ${ }^{32}$

Universality was initially viewed as a progressive development in the constitution of human rights because it erased differences linked to class. The inclusion of women within the universal category was trenchantly resisted by the gatekeepers from the outset, despite the egalitarian rhetoric. Indeed, the acclaimed (universal) Declaration of the Rights of Man and of the Citizen of 1789 did not in fact include women and Olympe de Gouges was sent to the guillotine soon after writing The Rights of Woman in $1791 .{ }^{33}$ First-wave feminism nevertheless continued to be drawn to the idea of universalism in the struggle to be 'let in' to the community of equals.

The appeal of universality collapsed as far as second-wave feminism was concerned by the late twentieth century - partly under the weight of postmodernism and partly because feminist scholars became more interested in the particularity of women's experiences. Some were of the view that a (masculinised) universal simply could not accommodate female corporeality and care or the idea that women spoke in a different moral voice. ${ }^{34}$ Disillusionment set in because of the way 'the category woman' (also conceived as a universal) occluded the raced, sexualised, able-bodied and aged identity of the female subject.

The prospect of a national charter of rights begs the question: can the universalism of human rights be reclaimed absent its masculinist bias? Siobhán Mullally

30 Jill Marshall, Humanity, Freedom and Feminism, Ashgate, Aldershot Hants, UK, 2005, pp. 13, 138.

31 Rachael Lorna Johnstone, 'Feminist Influences on the United Nations Human Rights Treaty Bodies' (2006) 28 Human Rights Quarterly 148, 151. For a competing point of view, see Fellmeth, who argues that international law is now compatible with feminism because of its emphasis on equality, inclusiveness, cooperation and care (Aaron Xavier Fellmeth, 'Feminism and International Law: Theory, Methodology, and Substantive Reform' (2000) 22 Human Rights Quarterly 658, 730-1).

32 For example: Margaret Thornton, The Liberal Promise: Anti-Discrimination Legislation in Australia, Oxford University Press, Melbourne, 1990.

33 Olympe de Gouges, The Rights of Woman, Translated by Val Stevenson, Pythia Press, London, 1989. De Gouges also wrote anti-slavery tracts and had criticised the leaders of the French Revolution. It is notable that de Gouges' treatise appeared just before Mary Wollstonecraft's famous A Vindication of the Rights of Woman (Second edition, Edited by Carol H. Poston, Norton, London, 1988 [1792]).

34 Marshall, Humanity, Freedom and Feminism, p. 52. The work of Carol Gilligan has been enormously influential. See Carol Gilligan, In a Different Voice: Psychological Theory and Women's Development, Harvard University Press, Cambridge, Mass., 1982. 
suggests that feminism cannot afford to turn its back on human rights despite its historical baggage. ${ }^{35}$ She suggests that the shift away from universalism is damaging for feminist theory and practice, particularly for an emancipatory agenda. ${ }^{36}$ Mullally suggests that putting a positive gloss on universality does not mean gender blindness, but gender and contextual sensitivity. ${ }^{37}$ This understanding of the rights-bearing subject emphasises personal identity, personal autonomy, personal development and intersubjectivity. Jill Marshall argues that respect for a person's private life is a central plank of human rights that is a provision of the European Convention for the Protection of Human Rights and Fundamental Freedoms $1950 .{ }^{38}$ While Australia does not have access to a supra-national court like members of the European Community to jostle it along, judges can look to the European Court's rulings in interpreting the UN conventions to which it is party, rather than taking refuge in strict legalism and an outdated notion of self-referentialism. The scrutiny of private sphere values - a key concern of second-wave feminism - would be welcome in light of the immunity under anti-discrimination legislation, but would it be feasible under a charter?

\section{UN Conventions}

In addition to the foundational UN Declaration of Human Rights, state parties have been most influenced by the International Covenant on Civil and Political Rights (ICCPR) and the International Covenant on Economic, Social and Cultural Rights (ICESCR). ${ }^{39}$ The ICCPR encompasses the formal rights associated with citizenship, which are essentially freedoms from state interference, whereas those contained in the ICESCR include material rights to education, housing, employment and wellbeing, although the focus is again directed to state action, albeit in a positive rather than a negative sense. Human rights instruments at the municipal or domestic level tend to oscillate between these two covenants, although procedural rights are invariably privileged over the substantive in accordance with the principles of liberal legalism. This suggests that we have not advanced very far beyond the civil rights associated with the Enlightenment, for there is continuing resistance and suspicion towards substantive rights of the kind associated with the ICESCR. Indeed, it is notable that the Australian Human Rights Commission Act 1986 (Cth) includes the rights set out in the ICCPR, but not those set out in the ICESCR. The Brennan Report also proposed

\footnotetext{
35 Mullally, Gender, Culture and Human Rights, pp. xxxi-xxxii.

36 Ibid, p. xxxi.

37 Ibid.

38 Jill Marshall, Personal Freedom Through Law? Autonomy, Identity and Integrity under the European Convention on Human Rights, Martinus Nijhoff, Leiden, 2009, pp. 1-3 et passim.

39 Sjoberg et al., 'A Sociology of Human Rights' 13.
} 
that the principles emanating from the two covenants be treated differently within a charter. The report recommended the possibility of initiating proceedings against a public authority in the case of civil and political rights but not in the case of economic, social and cultural rights. The different attitude towards rights claims regarding these two foundational covenants points to the difficulty in engendering new ways of thinking about human rights.

The bias in favour of formal rights associated with the ICCPR might also be linked to the long tradition of civil liberties within the Anglo-Australian legal tradition. Whitty et al., in justifying their study of civil liberties law in an age of human rights in the United Kingdom, refer to the 'somewhat swollen status of "human rights", which they set out to deflate, ${ }^{40}$ although there is no clear line of demarcation between civil rights and human rights, especially when the ICCPR is seen as the backbone of any domestic human rights instrument.

Distributive justice initiatives are highly contentious in a neo-liberal climate where the focus is on individual responsibility for one's life course. In any case, as Judy Fudge points out, courts are not a very good avenue for securing redistributive justice. ${ }^{41}$ Formalism is preferred by courts (and governments) because it allows dangerousness to be sloughed off. Not only does formalism preserve the myth of equality by adherence to strict equal treatment, it also limits the ambit of juridification, which is another source of concern with a charter of human rights. Detractors argue that it is for the legislature, not 'unelected judges', to make determinations about the allocation of resources. ${ }^{42}$ Formalism, however, means that the intractable issues of gender, race, class and power remain unchallenged.

The Universal Declaration of Human Rights in conjunction with the ICCPR and the ICESCR constitute the International Bill of Rights. The gender specificity of CEDAW has rendered it marginal to this international human rights core. Separatism has 'reinforced the idea that men's rights are universal and women's rights an afterthought'. ${ }^{43}$ Thus, CEDAW, the very instrument designed to benefit women, could have the effect of instantiating otherness and marginality.

40 Noel Whitty, Thérèse Murphy and Stephen Livingstone, Civil Liberties Law: The Human Rights Act Era, Oxford University Press, UK, 2005, p. 15. Cf. Chinkin, Wright and Charlesworth's reference to the 'triumphalism' of human rights in the 1990s. See Christine Chinkin, Shelley Wright and Hilary Charlesworth, 'Feminist Approaches to International Law: Reflections from another Century' in Doris Buss and Ambreena Manji (eds), International Law: Modern Feminist Approaches, Hart, Oxford, 2005, p. 23.

41 Judy Fudge, 'The Canadian Charter of Rights: Recognition, Redistribution, and the Imperialism of the Courts' in Tom Campbell, K. D. Ewing and Adam Tomkins, Sceptical Essays on Human Rights, Oxford University Press, UK, 2001, p. 349.

42 James Allan, 'The Effect of a Statutory Bill of Rights where Parliament is Sovereign: The Lesson from New Zealand', in Campbell et al., Sceptical Essays on Human Rights, p. 389.

43 Johnstone, 'Feminist Influences on the United Nations Human Rights Treaty Bodies', p. 151. Even more pointedly, Catharine MacKinnon poses the question, are women human? See Catharine A. MacKinnon, Are Women Human? And Other International Dialogues, Belknap, Harvard, Cambridge, Mass., 2006. 
Nevertheless, the diligent work of feminist international legal scholars has not been entirely in vain. In 2000, for example, the Convention on the Elimination of All Forms of Racial Discrimination (CERD) developed a specific recommendation regarding the impact on women of the conjunction of race and sex. ${ }^{44}$

Could a charter provide a way of invigorating CEDAW to compensate for its cautious and qualified implementation through the $S D A$ ? Would it be possible to draw on a range of international instruments, including CERD, the Convention on the Rights of Persons with Disabilities and the International Labour Organisation (ILO) Convention Concerning Discrimination in Employment and Occupation, in order to give effect to the wide-ranging injunctions in favour of women's equality contained in CEDAW?

\section{A National Human Rights Charter}

The introduction of human rights instruments with domestic application into Australia has been beset with ambivalence, as illustrated by the numerous abortive attempts to enact a domestic bill of rights. ${ }^{45}$ The only current federal human rights legislation, the Human Rights and Equal Opportunity Commission Act 1986 (Cth) (HREOCA), falls well short of a charter of human rights. ${ }^{46}$ Furthermore, as Peter Bailey points out, this Act displays a schizophrenia about human rights because it combines a hortatory approach to human rights in general with a framework for enforcement of the federal discrimination statutes (including the $S D A) .{ }^{47}$ Unsurprisingly, in light of the timidity towards human rights, the HRA (ACT) and the Victorian Charter - the only Australian human rights charters to date - are also cautious instruments that emphasise the rhetoricity of rights.

The Brennan Report similarly proposes that priority be given to the fostering of a human rights culture and conformity with human rights principles in public decision making. ${ }^{48}$ This softly-softly approach would undoubtedly make a charter more politically palatable for sceptics concerned about the agonistic

\footnotetext{
44 General Recommendation No XXV, Gender Related Dimensions of Racial Discrimination, Common the Elimination of Racial Discrimination, 56th Sess, annex V, 152, UN Doc A/55/18 (2000), <http://www.unhchr. ch/tbs/doc.nsf/(Symbol)/76a293e49a88bd23802568bd00538d83?Opendocument>

45 For an account of these attempts, see: Andrew Byrnes, Hilary Charlesworth and Gabrielle McKinnon, Bills of Rights in Australia: History, Politics and Law, UNSW Press, Sydney, 2009, pp. 23-43; Bailey, The Human Rights Enterprise in Australia and Internationally, pp. 141-52.

46 For detailed discussion, see: Bailey, The Human Rights Enterprise in Australia and Internationally, pp. 327-95.

47 Cf. ibid., p. 608.

48 Brennan Report, p. $131 \mathrm{ff}$.
} 
nature of human rights adjudication. ${ }^{49}$ The model proposes that litigation be resorted to as a shield rather than a sword, which is secured via an interpretative obligation imposed on courts and tribunals. ${ }^{50}$ That is, the mode does not confer enforceable rights of action against another party, but an obligation to interpret legislation in light of charter principles. While not empowered to invalidate legislation, a court would merely declare it incompatible with human rights; it would then be up to the legislature to act on the recommendation. Deference would allow legislative sovereignty to be upheld so that juridification was minimised.

It is notable that the Brennan model restricts human rights to individuals, thereby precluding their application to corporate entities, as occurred in Canada under the Charter. ${ }^{51}$ The downside is that there is no scope for an aggrieved person to call to account either another individual or a private corporation for a breach of human rights; the focus is entirely on public entities, other than if incidentally caught by a focus on adjudication (a public act). The effect of the public focus largely immunises private sector employment and corporate power, even though women generally are more likely to suffer a derogation of human rights at the hands of private rather than public actors. ${ }^{52}$

The way in which the Brennan proposal, the Victorian Charter and the HRA (ACT) all focus on public rather than private action supports the thesis of Sjoberg et al. that the human rights movement has emerged out of a context in which the state has weakened. ${ }^{53}$ This thesis of state deference to the market is underpinned by the neo-liberal deregulatory imperative, which became pronounced in Australia in the 1990s with the transference of power from government to the corporate sector. ${ }^{54}$ The state has not abandoned its regulatory role altogether, but, in effecting a liaison with the market, it has shifted its attention away from civil society. The result is that social justice and egalitarianism are treated as

\footnotetext{
49 Adam Tomkins, 'Introduction: On being Sceptical about Human Rights', in Campbell et al., Sceptical Essays on Human Rights, pp. 8-9.

50 For a detailed discussion and critique of the $H R A$ (UK) from the perspective of civil liberties, see Whitty et al., Civil Liberties Law.

51 This to avoid the expansive interpretation that developed under the Canadian Charter of Rights. For example: Kent Roach, 'Judicial Activism in the Supreme Court of Canada' in Brice Dickson (ed.), Judicial Activism in Common Law Supreme Courts, Oxford University Press, UK, 2007, p. 74. For detailed studies of the subversion of international human rights law by corporate power, see: Anna Grear, 'Human Rights - Human Bodies? Reflections on Corporate Human Rights Distortion, the Legal Subject, Embodiment and Human Rights Theory' (2006) 17 Law Critique 171; Tony Evans, 'International Human Rights Law as Power/Knowledge' (2005) 27 Human Rights Quarterly 1046.

52 Cf. Johnstone, 'Feminist Influences' 152.

53 Sjoberg et al., 'A Sociology of Human Rights'.

54 Mark Western, Janeen Baxter, Jan Pakulski, Bruce Tranter, John Western, Marcel van Egmond, Jenny Chesters, Amanda Hosking, Martin O'Flaherty and Yolanda van Gellecum, 'Neoliberalism, Inequality and Politics: The Changing Face of Australia' (2007) 42(3) Australian Journal of Social Issues 401.
} 
passé, while globalisation, free trade and the maximisation of corporate wealth are privileged. This does not bode well for relying on a charter in the interests of women and Others.

In light of the propensity of human rights to marginalise women, it is notable that a mere half-page of 460 pages in the Brennan Report is devoted to women. ${ }^{55}$ While it is proper to emphasise Indigenous rights, the intersection between race and gender is accorded short shrift, despite the (obvious) fact that at least half of all Indigenous people are female. The inference once again is that violations of women's rights are expendable or more properly conceptualised as aberrant manifestations of discrimination that fall within the rubric of CEDAW and the SDA.

A study by Byrnes et al. of the first year of operation of the HRA (ACT) found that while the legislation exerted a profound effect on the legislature and the executive, it had little effect on the judiciary. ${ }^{56}$ Indeed, there have been few discrimination cases in either the Australian Capital Territory or Victoria where the $H R A$ or the Charter has raised significant issues. The most notable involved an application for an exemption from the EOA (Vic.) by a company seeking to restrict gated community accommodation to people over fifty. ${ }^{57}$ Bell $\mathrm{J}$ provides a thoroughgoing analysis of equality in which he identifies it as the primary human right that 'permeates every pore of the Charter' ${ }^{58} \mathrm{He}$ makes it clear, furthermore, that equality is understood in substantive, not merely formalistic terms. Bell $\mathrm{J}$ is critical of a decision of Peedom $\mathrm{P}$ in the Australian Capital Territory, ${ }^{59}$ because the latter implied that the presence of a Charter made no difference to the exercise of the discretion. ${ }^{60}$

In a subsequent criminal case in Victoria, ${ }^{61}$ the Court of Appeal explored the interpretative role of the Court in light of the Victorian Charter (s. 32[1]): 'So far as it is possible to do so consistently with their purpose, all statutory provisions must be interpreted in a way that is compatible with human rights.'

The Court held that there was nothing in Section 32(1) that required an interpretation that would overrule parliamentary intention. ${ }^{62}$ The Court declined to follow Ghaidan, the leading case of the House of Lords, in interpreting a similar provision in the $H R A(\mathrm{UK}) .{ }^{63}$ In the process, the Court of

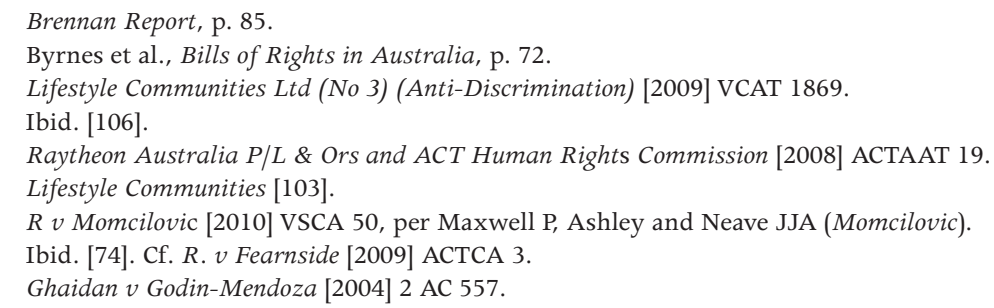


Appeal overruled a decision of Bell J in Kracke $v$ Mental Health Review Board, ${ }^{64}$ who had sought to interpret the Victorian Charter in accordance with the more expansive interpretation of Ghaidan. In support of its minimalist position, the Court of Appeal quoted at length from the parliamentary debates on the Victorian Charter, including the views of opponents of the Bill. ${ }^{65}$

What we see in Momcilovic is an attempt to read the dialogic model of human rights as nothing more than a signal from the judicial branch to the legislature that some action needs to be taken - as long as the judiciary itself does not respond by doing anything that might be construed as making law. Of course, it is a myth that judges do not make law, just as legislative intent itself is another myth. Indeed, in the case of the $S D A$ and other anti-discrimination texts, parliamentary intent is frequently left uncertain, which could expand the leeway of choice in a charter's encounter with discrimination legislation.

I suggest that it is not just a question of the legislative texts that is important in the novel hermeneutics of a human rights charter. The questions as to who are the judges, how they are appointed and what adjudicative stance they adopt are clearly of great moment. ${ }^{66}$ When Australian Acting Prime Minister Tim Fischer announced in 1996 after the trailblazing but contentious native title decisions of $M a b o^{67}$ and $W i k^{68}$ that the Howard Government would appoint 'Capital C Conservatives' to the High Court, ${ }^{69}$ six new judges were appointed (out of seven), which led to a discernible change in adjudicative style in a remarkably short time. ${ }^{70}$ A shift occurred from a purposive approach in anti-discrimination legislation jurisprudence, in which the remedial aims of the legislation were taken seriously, to a technocratic and legalistic approach that sloughed them off.

The exercise of discretion in interpreting human rights in context, as with discrimination and other progressive legislation, is the very point that disturbs human rights sceptics. ${ }^{71}$ Nevertheless, judges of all hues are likely to adopt a cautious approach to human rights legislation that is foreign to them or where deference to the legislature is the norm. Not only was this the experience, at least

\footnotetext{
64 [2009] VCAT 646.

65 Momcilovic [81]-[96].

66 Mark Tushnet, 'Sceptism about Judicial Review: A Perspective from the United States' in Campbell et al., Sceptical Essays on Human Rights, p. 360.

67 Mabo v Queensland (No. 2) (1992) 175 CLR 1.

68 Wik Peoples $v$ Queensland (1996) 187 CLR 1.

69 Nikki Savva, 'Fischer seeks a more conservative court', The Age (Melbourne), 5 March 1997, pp. 1-2.

70 For example: New South Wales $v$ Amery (2006) 230 CLR 174. See also: Margaret Thornton, 'Sex Discrimination, Courts and Corporate Power' (2008) 36 Federal Law Review 31; Margaret Thornton, 'Disabling Discrimination Legislation: The High Court and Judicial Activism' (2009) 15(1) Australian Journal of Human Rights 1.

71 For example: Allan, 'The Effect of a Statutory Bill of Rights Where Parliament is Sovereign', p. 389; Michael Pelly and Natasha Robinson, 'Charter risks clogging courts, says judge', The Australian, 12 October 2009.
} 
initially, in regard to the $H R A(\mathrm{UK}),{ }^{72}$ it is also apparent in the early Australian adjudicative experience of anti-discrimination legislation. ${ }^{73}$ The danger is that unless they are given very clear guidance, courts will fall back on a formalistic approach in preference to a substantive one. A formalistic approach could do more damage for women by creating unduly narrow precedents at the outset. We should therefore not allow ourselves to feel complacent before the warm, fuzzy glow that a discourse of human rights can engender, but should rigorously interrogate the content. In particular, we should not shrug our shoulders and accept unquestioningly the Brennan proposal that only state and public entities should be bound by a human rights charter.

\section{Freedom and Equality}

Freedom and equality - the twin variables of liberalism - are generally regarded as the pre-eminent human rights. ${ }^{74}$ They do not sit easily together, however, and their antinomy means that they perennially compete for ascendancy. ${ }^{75}$ Women's selfhood has been suppressed by the way freedom and autonomy have been used against them. ${ }^{76}$ The dilemma is invariably how to balance the right to freedom with the right to equality, although the idea of effecting a balance assumes that all claims are of comparable value. ${ }^{77}$ The invisibility of power within liberal legalism contributes to the myth that a state of equilibrium is attainable.

Philosophically, equality is a notoriously elusive concept despite its status as a-if not the - pre-eminent human right. Indeed, it is described by Julius Stone, following Aristotle, as 'the test of justice'.$^{78}$ Formal equality, or equality before the law, is a basic principle of liberal legalism and there is a sizeable gap between it and substantive equality, or equality of outcome - a disparity that I have alluded to in the underlying premises of the ICCPR and the ICESCR, respectively. The focus on formalism enhances the freedom of 'Benchmark Men' (those who are Anglo-Celtic, heterosexual, able-bodied and middle class,

\footnotetext{
72 Susan Easton, 'Feminist Perspectives on the Human Rights Act: Two Cheers for Incorporation' (2002) 8 Res Publica 21, 23.

73 Thornton, The Liberal Promise, pp. 198-206.

74 In contrast, Bailey identifies equality and dignity as the meta-principles of human rights. See Bailey, The Human Rights Enterprise in Australia and Internationally, p. 397. But see also Réaume, who suggests in her analysis of Canadian Charter jurisprudence that dignity could be used to deny equality claims (Denise G. Réaume, 'Discrimination and Dignity' in Fay Faraday, Margaret Denike and M. Kate Stephenson [eds], Making Equality Rights Real: Securing Substantive Equality under the Charter, Irwin Law, Toronto, 2006, pp. 123-77). 75 Wendy Brown, States of Injury: Power and Freedom in Late Modernity, Princeton University Press, NJ, 1995 , p. 67.

76 Catharine A. MacKinnon, Toward a Feminist Theory of the State, Harvard University Press, Cambridge, Mass., 1989, p. 216.

77 For critique of the idea of effecting a 'balance', see: Bailey, The Human Rights Enterprise in Australia and Internationally, pp. 104-10.

78 Julius Stone, Human Law and Human Justice, Maitland Publications, Sydney, 1968, p. 332.
} 
who favour a right-of-centre politics and who adhere, at least nominally, to a mainstream Christian religion). Provided that there is equality of opportunity at the outset, the law is satisfied; it is not concerned with outcomes, which involve distributive justice. In fact, substantive equality could be no more than a chimera - an ideal end point to which women and Others aspire, since compromise is unavoidable in real life.

All individuals necessarily live lives of interdependency, and the privileging of one person's freedom could cause a diminution of equality for another and vice versa. The introduction of institutional power into the equation skews the imbalance further. Employers, for example, are anxious to maximise their freedom by appointing whoever they wish on whatever terms they wish - a practice that has long contributed to bias towards women and disfavoured Others in the labour market, particularly as far as authoritative positions are concerned. Although state regulation of the terms and conditions of work is widely accepted, the idea that discrimination is unlawful is resisted because regulation is perceived to impede the freedom of the market. As Whitty et al. note, discrimination was a late development in the civil rights trajectory, ${ }^{79}$ pithily suggesting that courts were 'equality averse' ${ }^{80}$ Nevertheless, substantive equality, or some semblance of it, is realisable for women and Others only with the support of the state - fickle though it might be. The free market cannot be relied on to achieve equality of outcome when the modus operandi of competition is inequality. The neo-liberal state, however, has become increasingly reluctant to delimit market freedom by fostering equality measures, which has exacerbated the malaise surrounding the $S D A$.

The case of religious freedom should also be mentioned because of the deleterious impact of religion on women. ${ }^{81}$ As Gila Stopler points out, all mainstream religions are patriarchal, and deference to them operates as a statusenforcing mechanism that perpetuates women's inequality. ${ }^{82}$ Religion could also be imbricated with grounds such as race and ethnicity, which render it difficult to untangle issues of freedom and equality. The point is illustrated by the marked tensions arising from prescriptions pertaining to religious clothing, such as headscarves, which disproportionately affect women and girls. ${ }^{83}$ Their 'freedom of choice' could in fact be shaped by patriarchal religious leadership, family, community and state. ${ }^{84}$

\footnotetext{
79 Whitty et al., Civil Liberties Law, p. 390.

80 Ibid., p. 393.

81 Frances Raday, 'Culture, Religion, and Gender' (2002) 4 International Journal of Constitutional Law 663; Aileen McColgan, 'Class Wars Religion and (In)equality in the Workplace' (2009) 38 Industrial Law Journal 1, 5-7.

82 Gila Stopler, 'The Liberal Bind: The Conflict between Women's Rights and Patriarchal Religion' (2005) 31 Social Theory and Practice 191, 196.

83 For example, R. (on the application of Begum) v Head Teacher and Governors of Denbigh School [2006] UKHL 15. 84 Nicky Jones, 'Beneath the Veil: Muslim Girls and Islamic Headscarves in Secular France' (2009) 9 Macquarie Law Journal 47, 65.
} 
In omnibus State and Territory anti-discrimination statutes, the outlawing of discrimination on the ground of religious belief is treated as a mirror image of sex, race, sexuality or other ground, which highlights the 'one size fits all' approach to anti-discrimination legislation. ${ }^{85}$ Paradoxically, religion also occupies a privileged status in the legislative framework by virtue of the express exemptions that waive the proscription against discrimination for religious organisations. Despite the liberal state's express support for the equality of citizens regardless of belief or non-belief, all Australian anti-discrimination legislation defers to religion. ${ }^{86}$

In the $S D A$, a religious body is exempted from the non-discrimination principle in the case of an act or practice that conforms to the tenets of a particular religion or if it is 'necessary to avoid injury to the religious susceptibilities of adherents of that religion' ${ }^{87}$ This could apply to sex, marital status, pregnancy, potential pregnancy or family responsibilities in all operable areas, other than sexual harassment. There have been repercussions for women employed by religious organisations in respect of issues such as sexual orientation, de facto relationships, single motherhood and a preference for men in positions of authority. ${ }^{88}$ The legislative exemptions point to the fact that freedom of religion tends to be valued more highly than either equality or freedom of choice for women.

The point is clearly illustrated in the case of sexual orientation, which can intersect with sex, although not included in either the $S D A$ or dedicated federal legislation. At present, gays and lesbians experiencing discrimination have no option at the federal level other than to lodge a complaint for inquiry and recommendation under the AHREOCA. Sexual orientation also continues to be a highly contentious ground in the context of human rights, even in those jurisdictions where discrimination is proscribed. ${ }^{89}$ While the traditional privileging of religious organisations, together with their relative power in the community, suggests that the scales are likely to continue to be tilted in their favour, decisions from elsewhere suggest that a human rights instrument could

\footnotetext{
85 McColgan, 'Class Wars, Religion and (In)equality in the Workplace' 2.

86 A government review of exceptions to the EOA (Vic.) recommended that the religious exceptions be retained on all grounds other than race, impairment, physical features and age. See Scrutiny of Acts and Regulations Committee, Exceptions and Exemptions to the Equal Opportunity Act 1995-Final Report, Government Printer for the State of Victoria, Melbourne, 2009, Recommendations 48 and 49, pp. 62-4.

87 SDA, s. 37(d).

88 Margaret Thornton and Trish Luker, 'The Spectral Ground: Religious Belief Discrimination' (2009) 9 Macquarie Law Journal 71, 76-79; Reid Mortensen, 'A Reconstruction of Religious Freedom and Equality: Gay, Lesbian and De Facto Rights and the Religious School in Queensland' (2003) 3 Queensland University of Technology Law \& Justice Journal 320.

89 In an application for judicial review of a sexual orientation statute by a number of religious bodies in Northern Ireland, the applicants claimed that it was the orthodox belief of Christians that homosexual practices are sinful. See An Application for Judicial Review by the Christian Institute et al. [2007] NIQB 66.
} 
make a difference and restrain religious freedom. In $R$. (Amicus), ${ }^{90}$ various institutional claimants sought annulment of the Employment Equality (Sexual Orientation) Regulations 2003 (UK), arguing that their ability to adhere to their religious beliefs and carry on their teaching would be undermined if they were forced to employ people whose sexual practices were at odds with their own religious beliefs and practices. ${ }^{91}$ They failed to demonstrate discrimination. ${ }^{92}$ In an application for judicial review of a sexual orientation statute in Northern Ireland, the applicant religious bodies argued unsuccessfully that the right to freedom of thought, conscience and religion contained in Article 9 of the European Convention was absolute. ${ }^{93}$ While respectful of religious freedom, courts will not defer to religious freedom if it involves trammelling the selfworth and dignity of gays and lesbians, even when sexual orientation is also a proscribed ground under the legislation. Thus, even if the respondent regards homosexual conduct as sinful, European and Canadian courts bound by human rights principles have endeavoured to find a way to minimise its discriminatory effect in the interests of equality. ${ }^{94}$

In contrast, there is no question of 'balancing' rights in the case of an express exemption for religious bodies within Australian anti-discrimination legislation. The privileging of religion then perpetuates women's inequality in both the public and the private spheres. ${ }^{95}$ Perhaps, because of the UK experience, or because of the increasing political power of religion in Australia, ${ }^{96}$ both mainstream and fundamentalist religious bodies have expressed strong opposition to a charter of rights in the belief that it will diminish their freedom. ${ }^{97}$ Overtures not to proceed with a charter were made to the federal government in 2009 by mainstream religious leaders when the Brennan Report was released. ${ }^{98}$ Submissions were also made to the Victorian Attorney-General by a range of religious bodies regarding the repeal of wide-ranging exemptions for religion under the $E O A$ (Vic.). ${ }^{99}$

Powerful institutional forces therefore shape rights to freedom and equality in very particular ways. The immunity accorded the private corporate sector in

\footnotetext{
$90 R$. (Amicus \& Ors) v Secretary of State [2004] EWHC 860 (Admin).

91 Ibid. [30].

92 Ibid. [198]-[199].

93 An Application for Judicial Review by the Christian Institute et al.[2007] NIQB 66.

94 For example, Ontario Human Rights Commission v Brockie [2002] 22 DLR (4th) 174.

95 Cf. Stopler, 'The Liberal Bind' 194.

96 Marion Maddox, God Under Howard: The Rise of the Religious Right in Australian Politics, Allen \& Unwin, Sydney, 2005.

97 Patrick Parkinson, Christian Concerns with Charter of Rights, Paper presented at Conference on Cultural and Religious Freedom under a Bill of Rights, Canberra, August 2009. Mullally (Gender, Culture and Human Rights, p. 138) notes the occurrence of the same phenomenon in the United States.

98 Nicola Berkovic, 'Clergy unite over charter', The Australian, 23 October 2009, p. 1. It was subsequently reported that federal cabinet had rejected a national charter of rights. See Chris Merritt, 'State charter sets lawyers on path to isolation', The Australian, 19 February 2010, p. 29.

99 Scrutiny of Acts and Regulations (SARC) Committee, Exceptions and Exemptions to the Equal Opportunity Act 1995.
} 
the proposed charter, together with the privileged status accorded mainstream religions in anti-discrimination legislation, reveals once again that the imperative in favour of equality for women and Others is invariably trumped by power.

\section{Human Rights and Intersectionality}

As mentioned at the outset, Australian anti-discrimination legislation has been characterised by a one-dimensional and essentialist approach to grounds that has inhibited the ability to address multiple and intersecting strands of inequality. There is a substantial literature from the United States that shows how a unitary consciousness deleteriously affects Afro-American women for whom sex and race cannot be easily disaggregated. ${ }^{100}$ I suggest that invoking the equality prescript of a national charter could be a way of placing intersectionality on the agenda, although conceptualising gender equality merely as non-discrimination is clearly a problem in the present framework. ${ }^{101}$

Dao $v$ Australian Postal Commission ${ }^{102}$ is a paradigm of intersectionality arising from the dual grounds of sex and race in the Australian context. It involved two female Vietnamese postal workers who were precluded from obtaining permanency because they failed to satisfy the minimum body weight according to a scale based on height and sex. Because of the slighter body mass of Vietnamese women, the issues of race and sex could not be disaggregated, although intersectionality was not pursued, as the case foundered on constitutional grounds. ${ }^{103}$

The typical approach to multiple grounds in Australia is to address two or more grounds simultaneously rather than intersectionally. In Wiggins, ${ }^{104}$ the complainant alleged sex, sexual harassment and disability discrimination. Only the ground of disability was upheld, it being the view of McInnis FM that the serious depressive illness of the complainant affected her memory of the other two grounds. That is, the grounds were treated as discrete, although an intersectional approach might have considered whether the sexual harassment and the sex discrimination contributed to the mental illness.

\footnotetext{
100 Leading articles include: Kimberle Crenshaw, 'Demarginalizing the Intersection of Race and Sex: A Black Feminist Critique of Anti-Discrimination Doctrine, Feminist Theory and Antiracist Politics' (1989) University of Chicago Legal Forum 139; Angela P Harris, 'Race and Essentialism in Feminist Legal Theory' (1990) 42 Stanford Law Review 581.

101 Cf. Judith Squires, 'Intersecting Inequalities' (2009) 11 International Feminist Journal of Politics 496, 506.

102 Dao v Australian Postal Commission (1987) 162 CLR 317.

103 For discussion, see: Hilary Astor, 'A Question of Identity: The Intersection of Race and Other Grounds of Discrimination' in Race Discrimination Commissioner, The Racial Discrimination Act: A Review, AGPS, Canberra, 1995; Australian Law Reform Commission, Equality Before the Law, Pt I, pp. 63-9.

104 Wiggins $v$ Department of Defence - Navy [2006] FMCA 800.
} 
These cases were determined without the benefit of a charter and might be considered alongside Pearce ${ }^{105}$ — a case decided in the United Kingdom soon after the introduction of the HRA. The case involved a lesbian teacher who had been subjected to harassment at her school. The grounds arose from sexual orientation as well as sex. At that stage, there was no legislation outlawing discrimination on the ground of sexual orientation, so the complainant lodged a complaint on the ground of sex. Some of the harassing terms used by pupils, such as 'lezzie' and 'dyke', were clearly gendered, but the complaint was dismissed by the lower tribunals on the ground that there was no evidence that the pupils would have treated a male homosexual teacher more favourably than they treated the complainant. The gravamen of the appeal related to the $H R A$ (UK) (s. 3[1]), which requires a court to give effect to the European Convention on Human Rights 'so far as it is possible to do so' ${ }^{106}$ While Baroness Hale stated that the significance of the $H R A$ is that it enables courts to give legislation a different meaning to that previously held, ${ }^{107}$ sexuality was nevertheless found to be an irrelevant circumstance for the purpose of the comparison required by the Sex Discrimination Act 1975 (SDA [UK]) (s 5[3]): 'sex' in the Act meant gender, not 'sexuality'. It is conceivable that the outcome might have been different had the focus been directed to the gendered words alone but, by defining the relevant ground as sexual orientation rather than sex, the complainant was precluded from being able to succeed. In fact, as with Wiggins, the intersection of sex and sexuality was not addressed at all.

Despite the opportunity that the $H R A$ (UK) theoretically offered novel ways of thinking about intersectionality, the prevailing values of discrimination jurisprudence were not jettisoned in favour of equality. As Douzinas observes, the universal becomes the handmaiden of the particular at the hands of a legal system. ${ }^{108}$ Thus, 'human rights' can be just as restrictive as discrimination jurisprudence if the values of a charter are treated as subordinate to the statute under consideration, as suggested in the case of Momcilovic. Precedents, the norms of the relevant hermeneutic community, the subjectivity of individual judges and the spectre of religion are all going to play a role in shaping human rights in ways that comport with the status quo. The complainant in Pearce was harassed and denigrated by virtue of the twin signifiers of sex and sexuality. She was denied the right to a discrimination-free workplace as well as a right to equality. The primary focus of the decision was technocratic, privileging the specification of comparability under the $S D A$ (UK) rather than equality under the HRA (UK).

\footnotetext{
105 Pearce v Governing Body of Mayfield School [2001] EWCA Civ 1347.

106 Cf. HRA (ACT) s. 30.

107 Ibid. [14], per Lady Hale. A more robust approach to the question of the HRA (UK) effecting a change to an earlier ruling on the facts was adopted by the House of Lords a few years later. See Ghaidan $v$ GodinMendoza [2004] 2 AC 557. Legislation proscribing discrimination on the ground of sexual orientation had nevertheless been enacted by that time. See Employment Equality (Sexual Orientation) Regulations 2003 (UK). 108 Douzinas, 'The End(s) of Human Rights' 459.
} 
Even though there is no proviso in the HRA (UK) limiting the meaning of discrimination to that contained in the SDA (UK), as with the Victorian Charter, Pearce was dealt with as though the tacit understanding of equality for women was the equivalent of non-discrimination under the relevant statute. The case shows how the potential for a charter to address intersectional dilemmas in new ways can be frustrated by a conventional and conservative approach by judges towards interpretation. The focus on comparability in the SDA (UK) caused the court to lose sight of equality as the telos of the human rights statute, although the marshmallow wording favoured by the legislature - 'so far as it is possible to do so' - did not help. Reliance on an ostensibly depoliticised interpretative methodology of literalism allows courts to claim fidelity to parliamentary intention, even though this means privileging one constellation of moral values over another.

Australia, like the United Kingdom, favours a weak form of judicial review, as opposed to the strong form associated with the United States. ${ }^{109}$ That is, the weak form defers to parliamentary sovereignty, whereas the strong accords greater latitude to the judiciary to strike down legislation. The difficulty with antidiscrimination legislative texts is that they tend to be couched at a high level of abstraction so that legislative intention vis-a-vis intersectionality, for example, is unclear. Just because the issue has not been addressed in the past does not mean that an injunction in favour of equality in a charter can be accorded short shrift. The interpretative mandate requires judges to reconcile both texts, which provides scope for the creativity I am exhorting.

\section{Conclusion}

The warning of Whitty et al. that the passage of human rights legislation can induce a sense of euphoria in the belief that it will provide an instantaneous panacea for multiple shortcomings is salutary as Australia hesitantly acknowledges the possibility of a domestic culture of human rights. While human rights were initially greeted enthusiastically in jurisdictions such as Canada, successes led to a backlash against juridically enforced rights. ${ }^{110}$ Fudge links this backlash particularly to the success of gays and lesbians before the courts. ${ }^{11}$ UK legal feminists have not necessarily regarded the $H R A$ (UK) euphorically either, ${ }^{112}$ although some see it as contributing to a new and evolving rights

\footnotetext{
109 Mark Tushnet, The Rise of Weak-Form Judicial Review, Paper presented to ANU College of Law, The Australian National University, Canberra, May 2010.

110 Fudge, 'The Canadian Charter of Rights', pp. 337-8.

111 Ibid., p. 340.

112 Aileen McColgan, 'Women and the Human Rights Act' (2000) 51 Northern Ireland Legal Quarterly 417; Easton, 'Feminist Perspectives on the Human Rights Act'.
} 
jurisprudence. ${ }^{113}$ While the discourse of human rights does not carry the seeds of invidiousness and victimhood that discrimination discourse has acquired, I do not think that feminists in Australia can place their faith in a national charter of rights either.

I have shown that the ambit of the proposed legislation is limited and confined largely to the formal rights of the ICCPR, with the ICESCR and substantive equality carefully circumscribed. ${ }^{114}$ In addition, the immunity accorded corporations and the private sector, together with the privileging of powerful institutional interests, such as patriarchal religions, does not look as though it could revive an ailing SDA. The normative understanding of equality as non-discrimination also constitutes a barrier to novel ways of thinking about intersectionality because it falls back on conventional assumptions within discrimination jurisprudence, such as that of comparability. Of course, judges who are prepared to take a robust approach to interpreting indeterminate charter language can make a difference, but the hermeneutic pressure is invariably to opt for the safe course of action and privilege stare decisis and the status quo.

The ultimate paradox of a charter is that it is a creature of the state yet focuses solely on ills caused by state action. Inevitably, according to the norms of Westminster constitutionalism, the state is anxious to restrict the extent of judicial discretion and ensure deference to the legislature. The eighteenthcentury declarations of human rights were regarded as natural rights that were inalienable and independent of government. ${ }^{115}$ The twenty-first century incarnation is contingent on the state - a neo-liberal state where loyalties are more likely to be directed towards fostering entrepreneurialism and free trade in global markets than effecting substantive equality between all citizens in accordance with social-liberal ideals.

Nevertheless, as rights are the familiar language of progressive politics, which provide an avenue for redress, their rejection is just not a viable option. As Wendy Brown points out, feminists are compelled to accept the paradoxical nature of rights because they 'appear as that which we cannot not want' ${ }^{116}$ That is, we want the right to be free from exploitation, the right to autonomy, the right to be treated with dignity and the right to equality. We therefore cannot turn our backs on a federal charter - if, perchance, one should materialisedespite its likely defects and the vagaries of judicial interpretation, nor can

\footnotetext{
113 Joanne Conaghan and Susan Millns, 'Special Issue: Gender, Sexuality and Human Rights' (2005) 13 Feminist Legal Studies 1, 4.

114 This position contrasts with the Constitution of South Africa, which has been described as the most far-reaching example of the entrenchment of economic and social rights. See Katharine G. Young, 'Freedom, Want, and Economic and Social Rights: Frame and Law' (2009) 24 Maryland Journal of International Law 182,

115 Douzinas, 'The End(s) of Human Rights' 448.

116 Brown, 'Suffering Rights as Paradoxes' 23.
} 
we allow ourselves to be seduced by the siren call of the global at the expense of the local. It is up to us to engage with the mainstream and ensure that new meanings of equality are developed and that rights are not deployed against women and Others in the name of freedom for the powerful-especially private corporations and mainstream religions.

\section{Bibliography}

\section{Books and articles}

Allan, James, 'The Effect of a Statutory Bill of Rights where Parliament is Sovereign: The Lesson from New Zealand' in Tom Campbell, K. D. Ewing and Adam Tomkins, Sceptical Essays on Human Rights, Oxford University Press, UK, 2001.

Andrades, Carol, Intersections between 'General Protections' under the Fair Work Act 2009 (Cth) and Anti-Discrimination Law: Questions, Quirks and Quandaries, Working Paper No. 47, Centre for Employment and Labour Relations Law, University of Melbourne, Vic., 2009.

Astor, Hilary, 'A Question of Identity: The Intersection of Race and Other Grounds of Discrimination' in Race Discrimination Commissioner, The Racial Discrimination Act: A Review, AGPS, Canberra, 1995.

Attorney-General Hon. Robert McClelland MP and Minister for Finance and Deregulation Hon. Lindsay Tanner MP, Reform of Anti-discrimination Legislation, Media release, 21 April 2010, Parliament House, Canberra.

Bailey, Peter, The Human Rights Enterprise in Australia and Internationally, LexisNexis Butterworths, Chatswood, NSW, 2009.

Berkovic, Nicola, 'Clergy unite over charter', The Australian, 23 October 2009, p. 1.

Best, Susan J., 'Sexual Favoritism: A Cause of Action Under a "Sex-Plus" Theory' (2009) 30 Northern Illinois University Law Review 211.

Brown, Wendy, States of Injury: Power and Freedom in Late Modernity, Princeton University Press, NJ, 1995.

Brown, Wendy, 'Suffering Rights as Paradoxes' (2000) 7 Constellations 230. 
Bunch, Charlotte, 'Transforming Human Rights from a Feminist Perspective' in Julie Peters and Andrea Wolper (eds), Women's Rights, Human Rights, Routledge, New York, 1995.

Byrnes, Andrew, Charlesworth, Hilary and McKinnon, Gabrielle, Bills of Rights in Australia: History, Politics and Law, UNSW Press, Sydney, 2009.

Charlesworth, Hilary, 'Human Rights as Men's Rights' in Julie Peters and Andrea Wolper (eds), Women's Rights, Human Rights, Routledge, New York, 1995.

Chinkin, Christine, Wright, Shelley and Charlesworth, Hilary, 'Feminist Approaches to International Law: Reflections from another Century' in Doris Buss and Ambreena Manji (eds), International Law: Modern Feminist Approaches, Hart, Oxford, 2005.

Conaghan, Joanne and Millns, Susan, 'Special Issue: Gender, Sexuality and Human Rights' (2005) 13 Feminist Legal Studies 1.

Cook, Rebecca, 'Women's International Human Rights Law: The Way Forward' in Rebecca Cook (ed.), Human Rights of Women: National and International Perspectives, University of Pennsylvania Press, Philadelphia, 1994.

Crenshaw, Kimberle, 'Demarginalizing the Intersection of Race and Sex: A Black Feminist Critique of Anti-Discrimination Doctrine, Feminist Theory and Antiracist Politics' (1989) University of Chicago Legal Forum 139.

de Beauvoir, Simone, The Second Sex, Translated and edited by H. M. Parshley, Four Square, London, 1966.

de Gouges, Olympe, The Rights of Woman, Translated by Val Stevenson, Pythia Press, London, 1989.

Douzinas, Costas, 'The End(s) of Human Rights' (2002) 26 Melbourne University Law Review 445.

Easton, Susan, 'Feminist Perspectives on the Human Rights Act: Two Cheers for Incorporation' (2002) 8 Res Publica 21.

Eisenstein, Hester, 'A Dangerous Liaison? Feminism and Corporate Globalization' (2005) 69 Science \& Society 487.

Engle, Karen, 'International Human Rights and Feminisms: When Discourses keep meeting' in Doris Buss and Ambreena Manji (eds), International Law: Feminist Approaches, Hart, Oxford, 2005.

Evans, Tony, 'International Human Rights Law as Power/Knowledge' (2005) 27 Human Rights Quarterly 1046. 
Fellmeth, Aaron Xavier, 'Feminism and International Law: Theory, Methodology, and Substantive Reform' (2000) 22 Human Rights Quarterly 658.

Fudge, Judy, 'The Canadian Charter of Rights: Recognition, Redistribution, and the Imperialism of the Courts' in Tom Campbell, K. D. Ewing and Adam Tomkins, Sceptical Essays on Human Rights, Oxford University Press, UK, 2001.

Fudge, Judy and Owens, Rosemary (eds), Precarious Work, Women and the New Economy: The Challenge to Legal Norms, Hart Publishing, Oxford, 2006.

Gilligan, Carol, In a Different Voice: Psychological Theory and Women's Development, Harvard University Press, Cambridge, Mass., 1982.

Grear, Anna, 'Human Rights-Human Bodies? Reflections on Corporate Human Rights Distortion, the Legal Subject, Embodiment and Human Rights Theory' (2006) 17 Law Critique 171.

Harris, Angela P., 'Race and Essentialism in Feminist Legal Theory' (1990) 42 Stanford Law Review 581.

Hulls, Rob, Religious Freedom to be protected under Equal Opportunity Changes, Media release by the Victorian Attorney-General, 27 September 2009, Parliament House, Melbourne.

Johnstone, Rachael Lorna, 'Feminist Influences on the United Nations Human Rights Treaty Bodies' (2006) 28 Human Rights Quarterly 148.

Jones, Nicky, 'Beneath the Veil: Muslim Girls and Islamic Headscarves in Secular France' (2009) 9 Macquarie Law Journal 47.

McColgan, Aileen, 'Women and the Human Rights Act' (2000) 51 Northern Ireland Legal Quarterly 417.

McColgan, Aileen, 'Class Wars Religion and (In)equality in the Workplace' (2009) 38 Industrial Law Journal 1.

MacKinnon, Catharine A., Toward a Feminist Theory of the State, Harvard University Press, Cambridge, Mass., 1989.

MacKinnon, Catharine A., Are Women Human? And Other International Dialogues, Belknap, Harvard, Cambridge, Mass., 2006.

Maddox, Marion, God Under Howard: The Rise of the Religious Right in Australian Politics, Allen \& Unwin, Sydney, 2005.

Marshall, Jill, Humanity, Freedom and Feminism, Ashgate, Aldershot Hants, UK, 2005. 
Marshall, Jill, Personal Freedom Through Law? Autonomy, Identity and Integrity under the European Convention on Human Rights, Martinus Nijhoff, Leiden, 2009.

Merritt, Chris, 'State charter sets lawyers on path to isolation', The Australian, 19 February 2010, p. 29.

Mortensen, Reid, 'A Reconstruction of Religious Freedom and Equality: Gay, Lesbian and De Facto Rights and the Religious School in Queensland' (2003) 3 Queensland University of Technology Law \& Justice Journal 320.

Mullally, Siobhán, Gender, Culture and Human Rights: Reclaiming Universalism, Hart, Oxford and Portland, Ore., 2006.

Murphy, Thérèse, 'Feminism Here and Feminism There: Law, Theory and Choice' in Doris Buss and Ambreena Manji (eds), International Law: Modern Feminist Approaches, Hart, Oxford, 2005.

Parkinson, Patrick, Christian Concerns with Charter of Rights, Paper presented at Conference on Cultural and Religious Freedom Under a Bill of Rights, Canberra, August 2009.

Pelly, Michael and Robinson, Natasha, 'Charter risks clogging Courts, says Judge', The Australian, 12 October 2009.

Raday, Frances, 'Culture, Religion, and Gender' (2002) 4 International Journal of Constitutional Law 663.

Réaume, Denise G., 'Discrimination and Dignity' in Fay Faraday, Margaret Denike and M. Kate Stephenson (eds), Making Equality Rights Real: Securing Substantive Equality under the Charter, Irwin Law, Toronto, 2006.

Roach, Kent, 'Judicial Activism in the Supreme Court of Canada' in Brice Dickson (ed.), Judicial Activism in Common Law Supreme Courts, Oxford University Press, UK, 2007.

Savva, Nikki, 'Fischer seeks a more conservative court', The Age (Melbourne), 5 March 1997.

Sawer, Marian, 'Disappearing Tricks' (2008) 27(3) Dialogue: Academy of the Social Sciences in Australia 4.

Schaere, Enrique, 'Intragroup Discrimination in the Workplace: The Case for "Race Plus"' (2010) 45 Harvard Civil Rights-Civil Liberties Law Review 57.

Sjoberg, Gideon, Gill, Elizabeth A. and Williams, Norma, 'A Sociology of Human Rights' (2001) 48 Social Problems 11.

Squires, Judith, 'Intersecting Inequalities' (2009) 11 International Feminist Journal of Politics 496. 
Stamatopoulon, Elissavet, 'Women's Rights and the United Nations' in Julie Peters and Andrea Wolper (eds), Women's Rights, Human Rights, Routledge, New York, 1995.

Stone, Julius, Human Law and Human Justice, Maitland Publications, Sydney, 1968.

Stopler, Gila, 'The Liberal Bind: The Conflict between Women's Rights and Patriarchal Religion' (2005) 31 Social Theory and Practice 191.

Sukert, A. B., 'Marionettes of Globalization: A Comparative Analysis of Legal Protections for Contingent Workers in the International Community' (2000) 27 Syracuse J International Law \& Com 431.

Thornton, Margaret, The Liberal Promise: Anti-Discrimination Legislation in Australia, Oxford University Press, Melbourne, 1990.

Thornton, Margaret, 'Sex Discrimination, Courts and Corporate Power' (2008) 36(1) Federal Law Review 31.

Thornton, Margaret, 'Disabling Discrimination Legislation: The High Court and Judicial Activism' (2009) 15(1) Australian Journal of Human Rights 1.

Thornton, Margaret, 'Free Trade and Justice: A Discomfiting Liaison' in Kevin Walton, Helen Irving and Jacqui Mowbray (eds), Julius Stone: A Study of Influence, Federation Press, Sydney, (forthcoming).

Thornton, Margaret and Luker, Trish, 'The Spectral Ground: Religious Belief Discrimination' (2009) 9 Macquarie Law Journal 71.

Tomkins, Adam, 'Introduction: On being Sceptical about Human Rights' in Tom Campbell, K. D. Ewing and Adam Tomkins, Sceptical Essays on Human Rights, Oxford University Press, UK, 2001.

Tushnet, Mark, 'Sceptism About Judicial Review: A Perspective from the United States' in Tom Campbell, K. D. Ewing and Adam Tomkins, Sceptical Essays on Human Rights, Oxford University Press, UK, 2001.

Tushnet, Mark, The Rise of Weak-Form Judicial Review, Paper presented to ANU College of Law, The Australian National University, Canberra, May 2010.

Western, Mark, Baxter, Janeen, Pakulski, Jan, Tranter, Bruce, Western, John, van Egmond, Marcel, Chesters, Jenny, Hosking, Amanda, O'Flaherty, Martin and van Gellecum, Yolanda, 'Neoliberalism, Inequality and Politics: The Changing Face of Australia' (2007) 42(3) Australian Journal of Social Issues 401 . 
Sex Discrimination in Uncertain Times

Whitty, Noel, Murphy, Thérèse and Livingstone, Stephen, Civil Liberties Law: The Human Rights Act Era, Oxford University Press, UK, 2005.

Wollstonecraft, Mary, A Vindication of the Rights of Woman, Second edition, Edited by Carol H. Poston, Norton, London, 1988 [1792].

Young, Katharine G., 'The Minimum Core of Economic and Social Rights: A Concept in Search of Content' (2008) 33 Yale Journal of International Law 113.

Young, Katharine G., 'Freedom, Want, and Economic and Social Rights: Frame and Law' (2009) 24 Maryland Journal of International Law 182.

\section{Legislation}

Age Discrimination Act 2004 (Cth)

Charter of Human Rights and Responsibilities Act 2006 (Vic.)

Disability Discrimination Act 1992 (Cth)

Employment Equality (Sexual Orientation) Regulations 2003 (UK)

Fair Work Act 2009 (Cth)

Human Rights Act 1998 (UK)

Human Rights Act 2004 (ACT)

Racial Discrimination Act 1975 (Cth)

Sex Discrimination Act 1984 (Cth)

\section{Cases}

An Application for Judicial Review by the Christian Institute et al. [2007] NIQB 66

Dao v Australian Postal Commission (1987) 162 CLR 317

Ghaidan v Godin-Mendoza [2004] 2 AC 557

Kracke $v$ Mental Health Review Board [2009] VCAT 646

Lifestyle Communities Ltd (No. 3) (Anti-Discrimination) [2009] VCAT 1869

Mabo v Queensland (No. 2) (1992) 175 CLR 1

New South Wales v Amery (2006) 230 CLR 174

Ontario Human Rights Commission v Brockie [2002] 22 DLR (4th) 174 
Pearce v Governing Body of Mayfield School [2001] EWCA Civ 1347

R. (Amicus \& Ors) v Secretary of State [2004] EWHC 860 (Admin)

$R$. (on the application of Begum) $v$ Head Teacher and Governors of Denbigh School [2006] UKHL 15

R. v Fearnside [2009] ACTCA 3

R. v Momcilovic [2010] VSCA 50

Raytheon Australia P/L \& Ors and ACT Human Rights Commission [2008] ACTAAT 19

Re McBain: Ex parte Australian Catholic Bishops Conference (2002) 188 ALR 1

Wiggins v Department of Defence-Navy [2006] FMCA 800

Wik Peoples v Queensland (1996) 187 CLR 1

\section{Reports and miscellaneous primary sources}

Attorney-General Hon. Robert McClelland MP and Minister for Finance and Deregulation Hon. Lindsay Tanner MP, Reform of Anti-discrimination Legislation, Media release, 21 April 2010, Parliament House, Canberra.

Australian Law Reform Commission, Equality Before the Law: Justice for Women, Report No. 69, Australian Law Reform Commission, Sydney, 1994.

Commonwealth of Australia, National Human Rights Consultation Report, Commonwealth of Australia, Canberra, 2009 [Brennan Report].

European Convention on Human Rights

Scrutiny of Acts and Regulations Committee, Exceptions and Exemptions to the Equal Opportunity Act 1995-Final Report, Government Printer for the State of Victoria, Melbourne, 2009.

Senate Standing Committee on Legal and Constitutional Affairs, Report on the Effectiveness of the Commonwealth Sex Discrimination Act 1984 in Eliminating Discrimination and Promoting Gender Equality, Parliament of Australia, Canberra, 2008.

United Nations Convention on the Elimination of All Forms of Discrimination Against Women, United Nations, New York. 